\title{
EDITORIAL
}

\section{Nieuw gedachtegoed te over}

\author{
Henk G. van der Poel
}

Opnieuw overvloedig veel nieuwe gedachten en voer voor discussie in dit abstractnummer. De selectiecriteria van de PRIAS-studie zijn er niet voor niets: tumoren die er niet aan voldoen, hebben echt slechtere histologie na prostatectomie en de beoordeling van een positief chirurgisch snijvlak blijft subjectief en mogelijk een minder goede kwaliteitsmaat. Maar er zijn ook minder verwachte bevindingen: gebruik van de 68Ga-PSMA-PET-scan verhoogt de effectiviteit van de salvage radiotherapie na prostatectomie en zelfs bij recidiverende urine-incontinentie bij vrouwen zijn er gunstige resultaten met de artificiële sfincter. Er is nu een ureterstent die wel bevalt; en-bloc-hydrodissectie van blaastumoren blijkt in meer dan de helft van de gevallen mogelijk en DECT kan de compositie van stenen voorspellen. Bij meer dan de helft van de lymfoceles ontstaan de symptomen pas een maand na de ingreep of nog later. Het gebruik van MRI voor het nemen van biopten van de prostaat zou maar in minder dan $8 \%$ van de gevallen klinische consequenties hebben en het achterwege laten van systematische biopten naast MRI-targeted biopten mist significante tumoren. Aan de andere kant verhoogt het gebruik van targeted biopten de kans op het vinden van significante tumoren naast het gebruik van alleen systematische biopten. Kortom, het belooft weer een leerzame NVU-najaarsvergadering te worden.

$\overline{\triangle \text { dr. Henk G. van der Poel }}$

h.vd.poel@nki.nl

Tijdschrift voor Urologie,

Bohn Stafleu van Loghum, Houten, Nederland 